\title{
PENGAWASAN HAKIM KONSTITUSI DALAM SISTEM PENGAWASAN HAKIM MENURUT UNDANG-UNDANG DASAR NEGARA RI 1945
}

\author{
Titik Triwulan Tutik \\ Fakultas Syari'ah IAIN Sunan Ampel Surabaya \\ E-mail: tt_titik@yahoo.com
}

\begin{abstract}
This research is normative legal research. The objective of this research is firstly to clarify whether the essence of constitutional court's judges is not included in the term of judge in the 1945 constitution and Law number 242003 on judicial commission. Secondly, to know how model designs of controlling judges of constitutional court are after the issuance of Constitutional court's decision Number 005/PUU-IV/2006. The conclusion of research are the judges of constitutional court are regular judges bound to all judge regulations in Indonesia, because Indonesian constitution does not recognize different typologies of judges, the note of PAH I BP MPR that formulated amendment of the 1945 constitution the discussion surrounding the typologies of judges never took place; and the legal scholars, generally tend to generalize judges to include judges of constitutional courts. The control of constitutional court necessary to adopt integrated control system, that is internal control is done by Constitutional Court and external supervision mechanism conducted by external independent department, it is Judicial Commission. Based on those findings, in implementing an integrated supervision mechanism of Constitutional Court's Judges an amendment to the 1945 Constitution is recommended and revising the Law number 22 of 2004 on Judicial Commission and law number 24 of 2003 on Constitutional Court is urgently needed.
\end{abstract}

Key words: control on justice of Constitutional Court, the system of judge control, an integrated supervision mechanism

\begin{abstract}
Abstrak
Penelitian ini adalah penelitian hukum normatif. Tujuan dari penelitian adalah untuk mengetahui mengapa Hakim mahkamah konstitusi tidak termasuk dalam pengertian hakim menurut UUD 1945 dan UU No. 24 Tahun 2003 tentang Komisi Yudisial dan untuk mengetahui desains model pengawasan hakim mahkamah konstitusi pasca putusan Mahkamah Konstitusi Nomor 005/PUU-IV/2006. Hasil penelitian menyimpulkan bahwa hakim mahkamah konstitusi termasuk dalam kategori hakim yang didasarkan pada argument bahwa UUD 1945 tidak mengenal kategorisasi hakim dan hasil pembahasan rapat PAH I BP MPR tentang amandemen UUD 1945 tidak pernah membedakan makna hakim, serta para ahli hukum umumnya berpendapat bahwa makna hakim adalah semua hakim termasuk di dalamnya adalah hakim mahkamah konstitusi. Pengawasan terhadap hakim mahkamah konstitusi perlu mengadopsi sistem pengawasan terpadu, dimana pengawasan internal dilakukan oleh mahkamah konstitusi dan pengawasan eksternal dilakukan oleh lembaga independen yaitu Komisi Yudisial. Dalam rangka mewujudkan sistem pengawasan terpadu terhadap hakim mahkamah konstitusi, perlu dilakukan amandemen UUD 1945 dan segera mungkin melakukan revisi terhadap UU No. 22 Tahun 2004 tentang Komisi Yudisial dan UU No. 24 Tahun 2003
\end{abstract}

Kata kunci: pengawasan hakim mahkamah konstitusi, sistem pengawasan hakim, sistem pengawasan terpadu.

\section{Pendahuluan}

Hakim memiliki posisi penting dengan segala kewenangan yang dimilikinya, misalnya seorang hakim dapat mengalihkan hak kepemilikan seseorang, mencabut kebebasan warga negara, menyatakan tidak sah tindakan sewe- nang-wenang pemerintah terhadap masyarakat, bahkan memerintahkan penghilangan hak hidup seseorang. ${ }^{1}$ Wewenang dan tugas hakim yang

Dudu Duswara Machmudin, "Peranan Keyakinan Hakim dalam Memutus suatu Perkara di Pengadilan", Varia Peradilan 252 Oktober 2006, MA RI, hlm. 51 
besar demikian oleh karenanya harus dilaksanakan dalam rangka menegakkan hukum, kebenaran, dan keadilan sesuai kode etik tanpa pandang bulu dengan tidak membeda-bedakan orang seperti diatur dalam lafal sumpah seorang hakim, di mana setiap orang sama kedudukannya di depan hukum (equality before the law) dan hakim. ${ }^{2}$ Kewenangan hakim yang sangat besar tersebut di satu sisi menuntut tanggungjawab yang tinggi, sehingga putusan pengadilan yang diucapkan dengan irah-irah "Demi Keadilan berdasarkan Ketuhanan Yang Maha Esa" mengandung arti bahwa kewajiban menegakkan kebenaran dan keadilan itu wajib dipertanggungjawabkan secara horizontal kepada manusia, dan secara vertikal dipertanggungjawabkan kepada Tuhan Yang Maha Esa. ${ }^{3}$

Hakim untuk dapat melaksanakan semua fungsinya secara efektif, membutuhkan kepercayaan dari masyarakat dan pencari keadilan, karena dengan adanya kepercayaan itulah pengadilan dapat menyelesaikan perkara melalui jalur hukum dengan baik. ${ }^{4}$ Kepercayaan terhadap lembaga peradilan tidaklah muncul dengan sendirinya, tetapi harus melalui berbagai pembuktian bahwa badan peradilan dan hakim sungguh-sungguh menjunjung tinggi hukum serta menegakkan kebenaran dan keadilan secara benar dan konsisten. ${ }^{5}$ Oleh karenanya, dalam rangka menegakkan hukum dan keadilan itu hakim sebagai pelaksana utama dari fungsi pengadilan, harus mempunyai komitmen, tekad, dan semangat dalam membersihkan badan peradilan dari segala bentuk penyalahgunaan wewenang dan dalam rangka memulihkan kewibawaan badan peradilan serta upaya memulihkan ke-

2 JWM Engels, "Negara Hukum dan Hukum Negara: Les Quatres Saisons", Terjemahan Tristam P. Mulyono, J urnal ProJ ustitia Vol. XVIII No. 1 J anuari 2002, Fakultas Hukum Universitas Parahyangan, hlm. 7-20. Lihat J uga Martha Pigome"Implementasi Prinsip Demokrasi dan Nomokrasi dalam Struktur Ketatanegaraan RI Pasca Amandemen 1945", Jurnal Dinamika Hukum, Vol. 11 No. Mel 2001, hlm 323-335

3 Ketua Mahkamah Agung RI, "Pedoman Perilaku Hakim", Varia Peradilan, No. 252 Oktober 2006, hlm. 5-31

4 Charles Simabura, "Membangun Sinergis dalam Pengawasan Hakim", Jurnal Konstitusi, Vol. VII No. 2 Juli 2009, hlm. 43-62

5 Muchlis, "Hubungan Komisi Yudisial dengan Mahkamah Agung dalam Pengawasan Hakim", Jurnal Suloh, Vol. VI No. 2 Agustus 2008, hlm. 130 percayaan masyarakat kepada hakim. Salah satu hal penting yang disorot masyarakat untuk mempercayai hakim adalah perilaku hakim yang bersangkutan, baik dalam menjalankan tugas yudisialnya maupun dalam kesehariannya. ${ }^{6}$

Praktik penyalahgunaan wewenang di lembaga peradilan, disebabkan oleh banyak faktor antara lain dan terutama adalah tidak efektifnya pengawasan internal (fungsional) perilaku hakim pada badan peradilan. ${ }^{7}$ Menurut Mas Achmad Santosa, lemahnya pengawasan internal tersebut disebabkan oleh beberapa faktor, antara lain: kualitas dan integritas pengawas yang tidak memadai; proses pemeriksaan disiplin yang tidak transparan; belum adanya kemudahan bagi masyarakat yang dirugikan untuk menyampaikan pengaduan, memantau proses serta hasilnya (ketiadaan akses). ${ }^{8}$

Selain ketiga hal tersebut, menurut Ahmad Ashar, bahwa tidak efektifnya pengawasan internal disebabkan oleh dua faktor. Pertama, semangat membela sesama korps (esprit de corps) yang mengakibatkan penjatuhan hukuman tidak seimbang dengan perbuatan. Setiap upaya untuk memperbaiki suatu kondisi yang buruk pasti akan mendapat reaksi dari pihak yang selama ini mendapatkan keuntungan dari kondisi yang buruk itu. Kedua, tidak terdapat kehendak yang kuat dari pimpinan lem-

6 Lihat Berchah Petoewas, "Kewenangan Komisi Yudisial dalam Rangka Pengawasan Hakim Guna Melaksanakan Amanat UUD 1945", Jurnal Hukum Adil, Vol. I No. 3 Desember 2010, hlm. 219-229.

7 Ada 2 (dua) aspek yang terkait dengan permasalahan keberadaan lembaga peradilan ini: Pertama, lembaga peradilan telah menjadi lembaga yang diyakini sangat korup (judicial corruption) dan penuh dengan praktikpraktik yang sangat mencederai nilai-nilai keadilan seperti perdagangan perkara (mafia peradilan). Lihat A. Ahsin Thohari, "Desains Konstitutsional Komisi Yudisial dalam Sistem Ketatanegaraan Indonesia", Jurnal Legislasi Indonesia, Vol. VII No. 1 Maret 2010, hlm. 60-80. Kedua, Pengawasan kepada para hakim termasuk hakim agung yang dilakukan oleh Mahkamah Agung (MA) telah memunculkan berbagai permasalahan pada diri hakim, termasuk Hakim Agung. Permasalahan ini berkenaan dengan integritas dan kepribadian para hakim pada umumnya. Mahkamah Agung RI, 2003, Cetak Biru Pembaruan Mahkamah Agung RI, J akarta: Kerjasama Mahkamah Agung RI dengan LeIP, The Asia Foundation, USAID \& Kemitraan, hlm. 93.

8 Mas Achmad Santosa dalam Malik, "Perspektif Fungsi Pengawasan Komisi Yudisial Pasca Putusan Mahkamah Konstitusi (MK) Nomor 005/ PUU-IV/2006", J urnal Hukum Vol. 1 No. 2 Desember 2007, Universitas Bung Hatta, hlm. 22-34 
baga penegak hukum untuk menindaklanj uti hasil pengawasan internal terhadap hakim, sehingga membuka peluang bagi hakim yang terbukti melakukan pelanggaran hukum dan kode etik untuk mendapat 'pengampunan' dari pimpinan badan peradilan yang bersangkutan (tidak dikenakan sanksi sebagaimana mestinya). ${ }^{9}$

Kegagalan sistem pengawasan internal hingga saat ini belum dapat diatasi oleh lingkungan lembaga peradilan, walaupun pada waktu yang bersamaan juga dilaksanakan konsep peradilan satu atap (one roof system) khususnya pada lingkungan Mahkamah Agung (MA). Kondisi demikian justru menimbulkan kekhawatiran terjadinya monopoli kekuasaan, ${ }^{10}$ sehingga mendorong lahirnya gagasan ke arah pembentukan lembaga independen yang berada di luar MA, yang dapat mengimbangi agar tidak terjadi monopoli kekuasaan pada lembaga tersebut. Dalam rangka merealisasikan gagasan tersebut dibentuklah Komisi Yudisial (selanjutnya disebut KY) yang diharapkan menjadi external auditor, yang dapat mengimbangi pelaksana kekuasaan kehakiman. ${ }^{11}$

Kedudukan yuridis lembaga KY ditentukan dalam Pasal 24B ayat (1) UUD 1945 setelah perubahan: ${ }^{12}$

9 Ahmad Ashar, "Kewenangan Komisi Yudisial dalam Pengangkatan Hakim Agung Berdasarkan pada UU Nomor 22 Tahun 2004 tentang Komisi Yudisial", J urnal DAHA, Vol. I No. 42 J anuari 2009, hlm. 1-13

10 Dian Rosita, "Mengkaji Ulang Konsep Rule of Law dalam Pembaharuan Peradilan d Indonesia", Jurnal Konstitusi Vol. I No. 1 November 2008, Mahkaham Konstitusi RI, hlm. 6-20. Lihat juga Ayudya Widawati, "Seleksi Hakim Agung 2008, Mencari Hakim Agung yang Profesional, Berkualitas, Berintegritas, Akuntabel dan Transparan dalam Rangka Menegakkan Prinsip Check and Balances Kekuasaan Kehakiman di Indonesia", J urnal Hukum Vol. VII No. 1 J uni 2008, Fakultas Hukum UI, hlm. 27-36

11 Lihat Astriyani, "Mewujudkan Komisi Yudisial yang Ideal utuk Menjaga dan Menegakkan Kehormatan serta Keluhuran Martabat Hakim", J urnal Hukum Vol. III No. 8 Mei 2004, Fakultas Hukum UI Teropong, hlm. 30-42. Sementara ini pengawasan perilaku hakim yang dilakukan Ketua Muda Urusan Pengawasan dan Pembinaan (TUADA WASBIN) dipandang belum berhasil. Lihat juga Nurul Chotidjah, "Dinamika Implementasi Kewenangan Mahkamah Agung dan Komisi Yudisial setelah Amandemen Undang-Undang Dasar 1945", J urnal IImu Hukum Litigasi Vol. IX No. 3 2008, Fakultas Hukum Universitas Pasundan, hlm. 299-313

12 Lihat mengenai kedudukan Komis Yudisial ini yang cukup unik dalam A. Ahsin Thohari, "Kedudukan KomisiKomisi Negara dalam Struktur Ketatanegaraan Indonesia", J urnal Hukum J entera, Vol. III No. 12 AprilJ uni 2006, hlm. 38. Lihat juga, Zainal Arifin Mochtar bahwa Komisi Yudisial bersifat mandiri, mempunyai kewenangan pokok mengusulkan pengangkatan Hakim Agung, juga memiliki wewenang lain dalam rangka menjaga dan menegakkan kehormatan, keluhuran martabat, serta perilaku hakim. Dengan frasa "dalam rangka menjaga dan menegakkan kehormatan, keluhuran martabat, serta perilaku hakim

Menurut Mahkamah Konstitusi (MK), dalam batas-batas tertentu dapat diartikan sebagai pengawasan, yaitu pengawasan terhadap individu fungsionaris hakim lembaga peradilan. ${ }^{13}$ Operasionalisasi ketentuan Pasal 24B ayat (1) UUD 1945 ini dijabarkan dalam Undang-Undang Nomor 4 Tahun 2004 tentang Kekuasaan Kehakiman (UUKK 2004) dan Undang-Undang Nomor 22 Tahun 2004 tentang Komisi Yudisial (UUKY 2004).

Permasalahan muncul ketika aspek pengawasan $\mathrm{KY}$ sebagaimana telah disebutkan di atas dalam perspektif MA, dianggap telah memasuki wilayah pengawasan MA. Menurut MA, pengawasan $\mathrm{KY}$ selama ini yang memanggil beberapa Hakim Agung, dalam hubungan dengan perkara yang telah diadilinya telah mengakibatkan terganggunya hak konstitusional Hakim Agung yang dijamin kemerdekaannya oleh UUD 1945, selain itu juga menghancurkan independensi Hakim Agung dan hilangnya kebebasan hakim dalam mengadili. ${ }^{14}$ Berdasarkan alasan tersebut $K Y$ dianggap telah memasuki wilayah pengawasan MA yang meliputi teknis yudisial peradilan, puncaknya 31 hakim agung pada 10 Maret 2006 mengajukan permohonan terhadap peninjauan atas UUKY 2004 dan UUKK 2004 terhadap UUD 1945) ke MK dengan registrasi Nomor 005/ PUU-IV/ 2006.

dan Iwan Satriawan, "Efektivitas Sistem Penyelesaian Pejabat Komisi Negara di Indonesia", J urnal Konstitusi, Vol. VI No. 3 September 2009, hlm. 145

13 Putusan Mahkamah Konstitusi Nomor 005/PUU-IV/ 2006 tentang Uji Materiil Undang-Undang Nomor 22 Tahun 2004 tentang Komisi Yudisial dan Undang-Undang No. 4 tahun 2004 tentang Kekuasaan Kehakiman terhadap UUD 1945 dalam Yanis Maladi, "Benturan Asas Nemo J udex Indoneus In Propria Causa dan Asas lus Curita Novit: Telaah Yuridis Putusan Mahkamah Konstitusi Nomor 005/ PUU-IV/ 2006", J urnal Konstitusi, Vol. VII No. 2 2010, hlm. 10.

14 Permohonan Perkara Nomor 005/PUU-IV/ 2006 Perbaikan Tanggal 29 Maret 2006, dalam Mukhlis, loc. cit. 
Mahkamah Konstitusi melalui Amar Putusan Nomor 005/PUU/IV-2006, menyatakan beberapa hal. Pertama, permohonan para Pemohon menyangkut perluasan pengertian hakim menurut Pasal 24B ayat (1) UUD 1945 yang meliputi hakim konstitusi bertentangan dengan UUD 1945. Dengan demikian, hakim konstitusi tidak termasuk dalam pengertian hakim yang perilaku etiknya diawasi oleh KY. Pengawasan KY terhadap hakim Mahkamah Konstitusi akan mengganggu dan memandulkan MK sebagai lembaga pemutus sengketa kewenangan konstitusional lembaga negara. Kedua, permohonan para Pemohon menyangkut pengertian hakim menurut Pasal 24B ayat (1) UUDNRI 1945 tidak cukup beralasan. Oleh karena itu, permohonan para pemohon sepanjang menyangkut hakim agung tidak terdapat cukup alasan untuk mengabulkannya. MK tidak menemukan dasar konstitusionalitas dihapuskannya pengawasan KY terhadap hakim agung. Ketiga, menyangkut fungsi pengawasan, MK berpendapat bahwa segala ketentuan dalam UUKYyang menyangkut pengawasan dinyatakan bertentangan dengan UUDNRI 1945 dan tidak mempunyai kekuatan hukum mengikat karena terbukti menimbulkan ketidakpastian hukum (rechtsonzekerheid).

Amar putusan Mahkamah Konstitusi No. 005/ PUU-IV/ 2006 secara subtansial membatalkan beberapa pasal antara lain Pasal 1 angka 5, Pasal 20, Pasal 21, Pasal 22 ayat (1) huruf e dan ayat (5), Pasal 23 ayat (2), ayat (3), dan ayat (5), Pasal 24 ayat (1), dan Pasal 25 ayat (3) dan ayat (4) Undang-Undang Republik Indonesia No. 22 Tahun 2004 tentang Komisi Yudisial (Lembaran Negara Republik Indonesia Tahun 2004 Nomor 89, Tambahan Lembaran Negara Republik Indonesia Nomor 4415), serta Pasal 34 ayat (3) Undang-Undang Republik Indonesia Nomor 4 Tahun 2004 tentang Kekuasaan Kehakiman (Lembaran Negara Republik Indonesia Tahun 2004 Nomor 8, Tambahan Lembaran Negara Republik Indonesia Nomor 4358), karena bertentangan dengan Undang-Undang Dasar Negara Republik Indonesia Tahun 1945 dan tidak mempunyai kekuatan hukum mengikat; Pembatalan terhadap pasal-pasal dalam Undang-Undang Republik Indonesia Nomor 22 Tahun 2004 ten- tang Komisi Yudisial dan Undang-Undang Republik Indonesia Nomor 4 Tahun 2004 tentang Kekuasaan Kehakiman ini, mengakibatkan terjadinya kekosongan hukum (rechtsvacum) yang berfungsi sebagai dasar pijakan lembaga pengawas hakim konstitusi untuk melaksanakan pengawasan, sehingga diperlukan secepatnya pembentukan terhadap aturan hukum yang berkaitan dengan fungsi pengawasan terhadap hakim konstitusi.

\section{Permasalahan}

Berdasarkan paparan latar belakang di atas isu sentral dalam penelitian ini adalah mnengenai alasan-alasan Hakim Konstitusi tidak termasuk dalam Lingkup Pengawasan Komisi Yudisial. Dari isu sentral tersebut melahirkan dua isu hukum sebagai berikut. Pertama, Apakah pengertian Hakim Mahkamah Konstitusi tidak termasuk dalam pengertian hakim menurut Undang-Undang Dasar Negara Republik Indonesia Tahun 1945 dan Undang-Undang Nomor 22 Tahun 2004 tentang Komisi Yudisial; dan kedua, Lembaga manakah yang berwenang melakukan pengawasan terhadap Hakim Konstitusi dalam konteks pengawasan hakim Pascaputusan Mahkamah Konstitusi Nomor 005/ PUU-IV/ 2006?

\section{Metode Penelitian}

J enis penelitian ini adalah penelitian hukum normatif (dogmatic), ${ }^{15}$ yang ditujukan untuk menemukan dan merumuskan argumentasi hukum, melalui analisis terhadap pokok permasalahan. Pendekatan (approach) yang digunakan dalam penelitian ini ada empat jenis yaitu: pendekatan historis (historical approach), pendekatan perundang-undangan (statute approach); pendekatan perbandingan (comparative approach), pendekatan konsep (conceptual approach), dan pendekatan kasus (case appro-

15 Menurut J. Gijssel, Kajian Dogmatik hukum berfokus pada hukum positif, antara lain: (1) mempelajari aturan hukum dari segi teknis; (2) berbicara tentang hukum; (3) bicara hukum dari segi hukum; dan (4) bicara problem yang konkret. Lihat J. Gijssel dalam Philipus M. Hadjon, "Pengkajian IImu Hukum Dogmatik (Normatif)", J urnal Yuridika Vol. IX No. 6, November-Desember 1994, Fakultas Hukum Universitas Airlangga. 
ach). ${ }^{16}$ Dipergunakan lebih dari satu pendekatan dalam penelitian ini adalah untuk saling melengkapi antara satu pendekatan dengan pendekatan lainnya.

Langkah-langkah penelitian yang dilakukan adalah menghimpun bahan-bahan hukum baik bahan hukum primer maupun bahan hukum sekunder yang berkaitan dengan topik penelitian. Terhadap bahan hukum sekunder semuanya dicatat dengan menggunakan sistem kartu (card system). Kartu-kartu disusun berdasarkan pokok permasalahan penelitian dan sistematika penulisan yang telah dirumuskan. Semua hasil penelitian yang diperoleh dari bahan-bahan hukum tersebut di atas dicari hubungannya antar satu dengan lainnya dengan menggunakan penalaran deduktif dan induktif untuk menghasilkan proposisi dan konsep baik berupa definisi, deskripsi maupun klasifikasi sebagai hasil penelitian.

\section{Pembahasan \\ Kerangka Konseptual}

Kebebasan hakim pada lembaga peradilan hakikatnya merupakan benteng (safeguard) dari rule of law. ${ }^{17}$ Prinsip tersebut juga dianut secara universal sebagaimana tercermin dalam Basic Principles on the Independence of the J udiciary yang diadopsi oleh the Seventh United Nations Congress on the Prevention of Crime and the Treatment of Offenders, di Milan dari 26 Agustus sampai dengan 6 September 1985, dan disahkan dengan Resolusi Majelis Umum PBB Nomor 40/32 tanggal 29 November 1985 dan Nomor 40/ 146 tanggal 13 Desember 1985.

Independensi hakim pada lembaga peradilan hakekatnya merupakan prasyarat yang po-

16 Terry Hutchinson, Researching and Writing in Law, Lawbook. Co., Pyrmont-NSW-Sydney, 2002, hlm. 29. Lihat juga Peter Mahmud Marzukki, "Jurisprudence As Sui Generis Discipline", J urnal Hukum Yuridika Vol. XVII No. 4 J uli 2002, FH Universitas Airlangga Surabaya, hlm. 309-310

17 Tentang Konsep Negara Hukum ini dapat dibaca secara lengkap dalam Sri Soemantri, "Sistem Pemerintahan Republik Indonesia", J urnal Mimbar Hukum Vol. X No. 3 Nopember 2002, hlm. 190; Yance Arizona, "Konstitusi dalam Intaian Neoliberalisme", J urnal Konstitusi Vol. I No. 1 November 2008, Mahkamah Konstitusi RI, hlm. 27; R.M. Ananda B. Kusuma, "Teori Konstitusi dan UUD 1945", J urnal Konstitusi, Vol. III No. 2 Mei 2006, hlm. 152; dan Abdul Latif, "Pilpres dalam Perspektif Koalisi Multipartai", J urnal Konstitusi, Vol. VI No. 3 September 2009, hlm. 25-26 kok bagi terwujudnya cita negara hukum dan merupakan jaminan bagi tegaknya hukum dan keadilan. ${ }^{18}$ Prinsip ini melekat sangat dalam dan harus tercermin dalam proses, pemeriksaan dan pengambilan keputusan atas setiap perkara dan terkait erat dengan independensi pengadilan sebagai institusi peradilan yang berwibawa, bermartabat, dan terpercaya. ${ }^{19}$

Menurut Mahkamah Konstitusi, Independensi hakim dan pengadilan terwujud dalam kemerdekaan hakim, baik sendiri-sendiri maupun sebagai institusi, dari pelbagai pengaruh yang berasal dari luar diri hakim berupa intervensi yang bersifat mempengaruhi secara langsung berupa bujuk rayu, tekanan, paksaan, ancaman, atau tindakan balasan karena kepentingan politik atau ekonomi tertentu dari pemerintah atau kekuatan politik yang berkuasa, kelompok atau golongan tertentu, dengan imbalan atau janji imbalan berupa keuntungan jabatan, keuntungan ekonomi, atau bentuk lainnya.

Kemerdekaan hakim sangat berkaitan erat dengan sikap tidak berpihak atau sikap imparsial hakim, baik dalam pemeriksaan maupun dalam pengambilan keputusan. Hakim yang tidak independen tidak dapat diharapkan bersikap netral atau imparsial dalam menjalankan tugasnya. ${ }^{20}$ Demikian pula lembaga peradilan yang tergantung pada organ lain dalam bidang tertentu dan tidak mampu mengatur dirinya secara mandiri juga akan menyebabkan sikap yang tidak netral dalam menjalankan tugasnya. Kemerdekaan tersebut juga memiliki aspek yang berbeda. Kemerdekaan fungsional, me-

18 A.V. Dicey menentukan tiga tolok ukur dari keberadaan negara hukum (rule of law) yaitu: (1) supremasi hukum (supremacy of law); (2) persamaan dihadapan hukum (equality before the law); dan (3) konstitusi yang berdasarkan pada hak-hak perorangan (the constitution based on individual rights). Lihat Denny Indrayana, "Negara Hukum Indonesia Pasca Soeharto: Transisi Menuj u Demokrasi vs Korupsi", J urnal Konstitusi Vol. 1 No. 1 J uli 2004, Mahkamah Konstitusi RI, hIm. 101. Lihat juga Bambang Heryanto, "Refleksi Politik Hukum Pelanggaran Hak Asasi Manusia di Indonesia", Jurnal IImu Hukum Yuridika Vol. 17 No. 4 J uli-Agustus 2002, Fakultas Hukum Universitas Airlangga, hlm. 334

19 A. Ahsin Thohari, "Jalan Terjal Konstitusionalisme Indonesia", Jurnal Konstitusi Vol. 1 No. 1 Juli 2004, Mahkamah Konstitusi RI, hlm. 161

20 P. Wignjosumarto, "Peran Hakim Agung dalam Penemuan Hukum dan Penciptaan Hukum pada Era Reformasi dan Transformasi", Varia Peradilan, No. 251 Oktober 2006, hlm. 69 
ngandung larangan bagi cabang kekuasaan yang lain untuk mengadakan intervensi terhadap hakim dalam melaksanakan tugas justisialnya. Namun demikian kemerdekaan tersebut tidak pernah diartikan mengandung sifat yang mutlak, karena dibatasi oleh hukum dan keadilan. ${ }^{21}$

Kemerdekaan hakim dimaksud juga diartikan bahwa hakim bebas memutus sesuai dengan nilai yang diyakininya melalui penafsiran hukum, ${ }^{22}$ walaupun putusan yang didasarkan pada penafsiran dan keyakinan demikian mungkin berlawanan dengan mereka yang mempunyai kekuasaan politik dan administrasi (asas resjudicata facit jus). ${ }^{23}$ Jika putusannya tidak sesuai dengan keinginan pihak yang berkuasa, hal itu tidak dapat dijadikan alasan untuk melakukan tindakan pembalasan terhadap hakim baik secara pribadi maupun terhadap kewenangan lembaga peradilan ("... when a decision adverse to the beliefs or desires of those with political power, can not affect retribution on the judges personally or on the power of the court"). ${ }^{24}$

Kemerdekaan hakim harus dimaknai tetap dalam batas-batas yang ditentukan oleh hukum dan dalam rangka menerapkan hukum secara adil (fair). Dalam pandangan J ohn Ferejohn, independensi peradilan adalah sebuah konsep yang relatif, bukan absolut. Selengkapnya, Ferejohn menyatakan:

21 Lihat M. Laica Marzuki, "Kesadaran Berkonstitusi dalam Kaitan Konstitusionalisme", Jurnal Konstitusi, Vol. VI No. 3 September 2009, hlm. 31. Lihat juga Didik Widitrismiharto, "Pengutan Fungsi Pengawasan Komisi Yudisial Berada di Persimpangan Jalan: Sebuah Kajian tentang Reformasi Peradilan", J urnal Yustika, Vol. X No. 2 Desember 2007, hlm. 309-321. Juga lihat dalam M. Laica Marzuki, "Paradigma Kedaulatan Rakyat dalam Perubahan Undang-Undang dasar 1945", J urnal Legislasi Indonesia, Vol. VII No. 1 Maret 2010, hlm. 139

22 Tentang interpretasi hukum oleh hakim ini dapat dibaca dalam Soewoto, "Metode Interpretasi Hukum Terhadap Konstitusi", J urnal Hukum Yuridika Vol. V No. 1 J anuari-Februari 1990, FH Universitas Airlangga, hlm. 31-32; Wij ayanto Setiawan, "Peran Hakim Agung dalam Penemuan Hukum (Rechtsvinding) dan penciptaan Hukum (Rechtsschepping) pada Era Reformasi dan Transformasi", J urnal Perspektif Hukum Vol. VII No. 2 November 2007, FH Univ. Hang Tuah Surabaya, hlm. 88-89

23 Manfred Simon, "The Role of Judges in a Rapidly Changing Society", dalam Simon Shetreet, and J. Deschenes (eds), 1985, Judicial Independence: The Contemporary Debate, Dordrecht: Martinus Nijhoff Publisher, hlm. 554

24 Theodore L. Becker dalam Herman Schwartz (2003) sebagaimana dikutip dalam Ibid.
"One definitional problem is that judicial independence is a relative, not an absolute, concept. The following definition of 'dependency' highlights the relative nature of judicial independence: in $[A]$ person or institution [is] ... dependent ... [if] unable to do its job without relying on some other institution or group."

(Satu definisi bahwa independensi peradilan adalah relatif, tidak absolut, konseptual. Berdasarkan definisi tersebut, maka independensi bersift relative di mana seseorang atau institusi dikatatakan dependen jika dalam bekerja tidak bergantung dari institusi atau kelompok lain). ${ }^{25}$

Berdasarkan pendapat tersebut, independensi peradilan adalah keadaan di mana peradilan dapat atau sanggup menjalankan tugasnya tanpa memiliki ketergantungan pada pihak lain. Relativitas konsep independensi peradilan ini akhirnya memang selalu memicu perdebatan yang pada akhirnya diterjemahkan secara berbeda-beda di setiap negara.

Independensi peradilan dalam perkembangannya harus bersanding dengan konsep lain yang harus berdampingan secara harmonis, yakni akuntabilitas publik (public accounta-bility). International Bar Association Code of Minimum Standards of J udicial Independence dalam angka 33 menentukan

It should be recognised that judicial independence does not render the judges free from public accounttability, however, the press and other institutions should be aware of the potential conflict between judicial independence and excessive pressure on judges

(harus diakui bahwa independensi peradilan tidak dengan sendirinya membebaskan hakim dari akuntabilitas publik, meski demikian, tekanan dan intervensi lembaga lain berpotensi melahirkan kon-

25 John Ferejohn, "Independent J udges, Dependent Judiciary: Explaining Judicial Independence," 72 Southern California Law Review 353 (1999) sebagaimana dikutip The Asia Foundation, Oktober 2003, Judicial Independence Overview and CountryLevel Summaries, Asian Development Bank Judicial Independence Project, RETA No. 5987, submitted by The Asia Foundation, hlm. 2. 
flik antara independensi peradilan dan tekanan terhadap hakim). ${ }^{26}$

Berdasarkan ketentuan di atas, maka independensi kekuasaan kehakiman atau peradilan itu memang tidak boleh diartikan secara absolut. Salah satu rumusan penting konferensi International Commission of Jurist menggarisbawahi bahwa "Independence does not mean that the judge is entitled to act in an arbitrary manner" (independensi tidak berarti bahwa hakim tanpa dasar untuk bertindak). Oleh karena itu, sejak awal munculnya gagasan mengubah UUD 1945 telah muncul kesadaran bahwa sebagai pengimbang inde-pendensi dan untuk menjaga kewibawaan kekuasaan kehakiman, perlu diadakan pengawasan eksternal yang efektif di bidang etika kehakiman seperti beberapa negara, yaitu dengan dibentuknya Komisi Yudisial. ${ }^{27}$

Menurut Paulus E. Lotulung, batasan atau rambu-rambu yang harus diingat dan diperhatikan dalam implementasi kebebasan itu adalah terutama aturan-aturan hukum itu sendiri. ${ }^{28}$ Ketentuan-ketentuan hukum, baik segi prosedural maupun substansial atau materiil merupakan batasan bagi kekuasaan kehakiman agar dalam melakukan independensinya tidak melanggar hukum, dan bertindak sewenang-wenang. Hakim adalah subordinated pada hukum dan tidak dapat bertindak contra legem. Selanjutnya, harus disadari bahwa kebebasan dan independensi tersebut diikat pula dengan pertanggungjawaban atau akuntabilitas, di mana keduanya pada dasarnya merupakan dua sisi koin mata uang yang sama. Tidak ada kebebas-

26 International Bar Association, 22 ${ }^{\text {nd }}$ October 1982, International Bar Association Code of Minimum Standards of Judicial Independence, The Jerussalem Approved Standards of the $19^{\text {th }}$ IBA Biennial Conference held on Friday dalam A. Ahsin Thohari, 2010, loc. cit.

27 Jimly Asshiddiqie, "Pemilihan Langsung Presiden dan wakil Presiden", J urnal Hukum Vol. XXVII No. 51 2004, Fakultas Hukum UII Yogyakarta, hlm. 12. Lihat juga Saldi Isra, "Putusan Mahkamah Konstitusi Nomor 005/ PUU-IV/ 2006: Isi, Implikasi dan Masa Depan Komisi Yudisial", J urnal II miah Hukum Legality Vol. XV No. 1 2007, Fakultas Hukum Universitas Muhammadyah Malang, hlm. 40

28 Paulus E. Lotulung, Kebebasan Hakim dalam Sistem Penegakan Hukum, Makalah disampaikan dalam Seminar Pembangunan Hukum Nasional VIII, diselenggarakarn oleh Badan Pembinaan Hukum Nasional Departemen Kehakiman dan Hak Asasi Manusia RI), Denpasar, 14 -18 juli 2003, hlm. 7 an mutlak tanpa tanggung jawab. Dengan perkataan lain dapat dipahami bahwa dalam konteks kebebasan hakim haruslah diimbangi dengan pasangannya yaitu akuntabilitas peradilan (judicial accountability). ${ }^{29}$

Wujud akuntabilitas publik dalam pengawasan, bahwa walaupun hakim sebagai pemegang kekuasaan kehakiman haruslah independen, tetapi independensi tersebut tidak boleh menjadikan hakim sebagai pelaku yang tidak terkontrol. Menurut Lintong 0 . Siahaan, pada prinsipnya peran hakim dalam memutuskan perkara dapat diuji melalui tiga hal, yaitu social change, despuite dan statement. Berdasarkan parameter tersebut, dalam menjalankan kewenangannya hakim termasuk juga hakim konstitusi memiliki kebebasan yudisial dalam memutus sengketa, meski demikian ia bukanlah corong undang-undang (la bouche de la loi) yang hanya sekedar menuangkan dari apa yang ada dalam aturan hukum, ${ }^{30}$ tetapi ia memiliki kompetensi perilaku, yang meliputi perilaku secara individu (personal) maupun perilaku yudisial. Kompe-tensi hakim tersebut merupakan the authority of judges judicial behaviour (kemandirian perilaku hakim dalam kekuasaan yudisial). Dengan kedudukan ini hakim menikmati otonomi yang tinggi dan tanpa batas, meski demikian hakim sebagai pelaku kekuasaan kehakiman, tidak bisa dibiarkan begitu saja menjalankan fungsi kekuasaan yudisial tanpa pengontrol dan pengimbang dari lembaga eksternal. Alasannya, hal ini dapat melahirkan kekuasaan yudisial yang absolut (tirani yudisial), yaitu suatu format ketatanegaraan (pranata sosial) yang sama buruknya dengan tirani eksekutif dan tirani legislatif dimana kekuasaan yudisial dengan otoritasnya dapat menciptakan sah terhadap hal yang tidak sah (necessitas facit liticum qoad atau non est liticum), meski demikian mereka tidak dapat tersentuh oleh cara apapun dan lembaga manapun, termasuk

29 Lihat Nurhasan, "Sistem Politik Peradilan Indonesia, Hakim dan Komisi Yudisial dalam Mewujudkan Penegakkan Hukum yang Efektif dan Efisien, Jurnal IImu HUkum Litigasi Vol. IX No. 3 2008, Fakultas Hukum Universitas pasundan, hlm. 251

30 Lintong O. Siahaan, "Peran Hakim dalam Pembaharuan Hukum di Indonesia", J urnal Hukum dan Pembangunan, Tahun Ke-36 No. 1 J anuari-Maret 2006, hlm. 36 
oleh lembaga yang berwenang dalam melaksanakan pengawasan. ${ }^{31}$ Menurut Oemar Seno Adji, kebebasan hakim tidak berarti bahwa ia bebas di dalam menentukan kerangka umum dan prinsip-prinsip dasar daripada kegiatan peradilan dan organisasinya, tetapi suatu kebebasan harus berdampingan dengan dua perkara, yaitu factuele virjheid, dan persoonlijke vrijheid. ${ }^{32}$

Paulus E. Lotulung berpendapat, untuk mewujudkan independensi hakim, maka setiap independensi perlu diimbangi dengan tanggungjawab dalam bentuk akuntabilitas dan transparansi. Oleh sebab itu hakim akan memperoleh kepercayaan publik jika mampu menjalankan independensinya yang dibarengi dengan 2 dua langkah yang saling terkait erat, yaitu pengelolaan administrasi; dan pengawasan (control). ${ }^{33}$

Berdasarkan pendapat tersebut, dapat disimpulkan, bahwa kemerdekaan hakim di satu sisi, haruslah diimbangi dengan akuntabilitas di sisi lain. Keduanya, kemerdekaan dan akuntabilitas bagaikan dua sisi mata uang. Kedua unsur tersebut hadir bersamaan, tidak berdiri sendiri, karena itu harus dikatakan bahwa tidak ada kebebasan tanpa akuntabilitas. Paulus E. Lotulung selanjutnya mengatakan:

Perlunya independensi tidak berarti bahwa hakim tidak dapat dikritik atau diawasi. Sebagai keseimbangan dari independensi, selalu harus ada terdapat akuntabilitas dan tanggungjawab untuk mencegah ketidakadilan. Mekanisme pengawasan itu harus dikembangkan oleh lembaga peradilan itu sendiri dan masyarakat dalam pengertian untuk menjamin akuntabilitas seorang hakim. ${ }^{34}$

Berdasarkan kenyataan tersebut, maka keberadaan lembaga pengawas hakim yang mandiri, dan bebas dari campur tangan lembaga lain

31 Hugo Black (Hakim Agung Amerika Serikat), pernah mengatakan, "There can be no equal justice where the kind of trial a man gets depends on the amount of money he has". Lihat Saharuddin Daming, "Wabah The Dark J uctice dan Tirani Peradilan", Koran Tempo, Selasa 26 April 2011. Lihat juga Nurul Chotidjah, "Eksistensi Komisi Yudisial dalam Mewujudkan Kekuasaan Kehakiman yang Merdeka", Jurnal IImu Hukum Syiar Madani Vol. XII No. 2 J uli 2010, hlm. 170

32 Oemar Seno Adji, 1985, Peradilan Bebas Negara Hukum. J akarta: Erlangga, hlm. 109

33 Paulus E. Lotulung, Op. Cit., hlm. 18

34 Ibid. mutlak diperlukan dalam rangka menegakkan kehormatan, menjaga keluhuran martabat serta perilaku hakim dalam rangka mewujudkan pemerintahan yang baik dan bersih (good governance). ${ }^{35}$

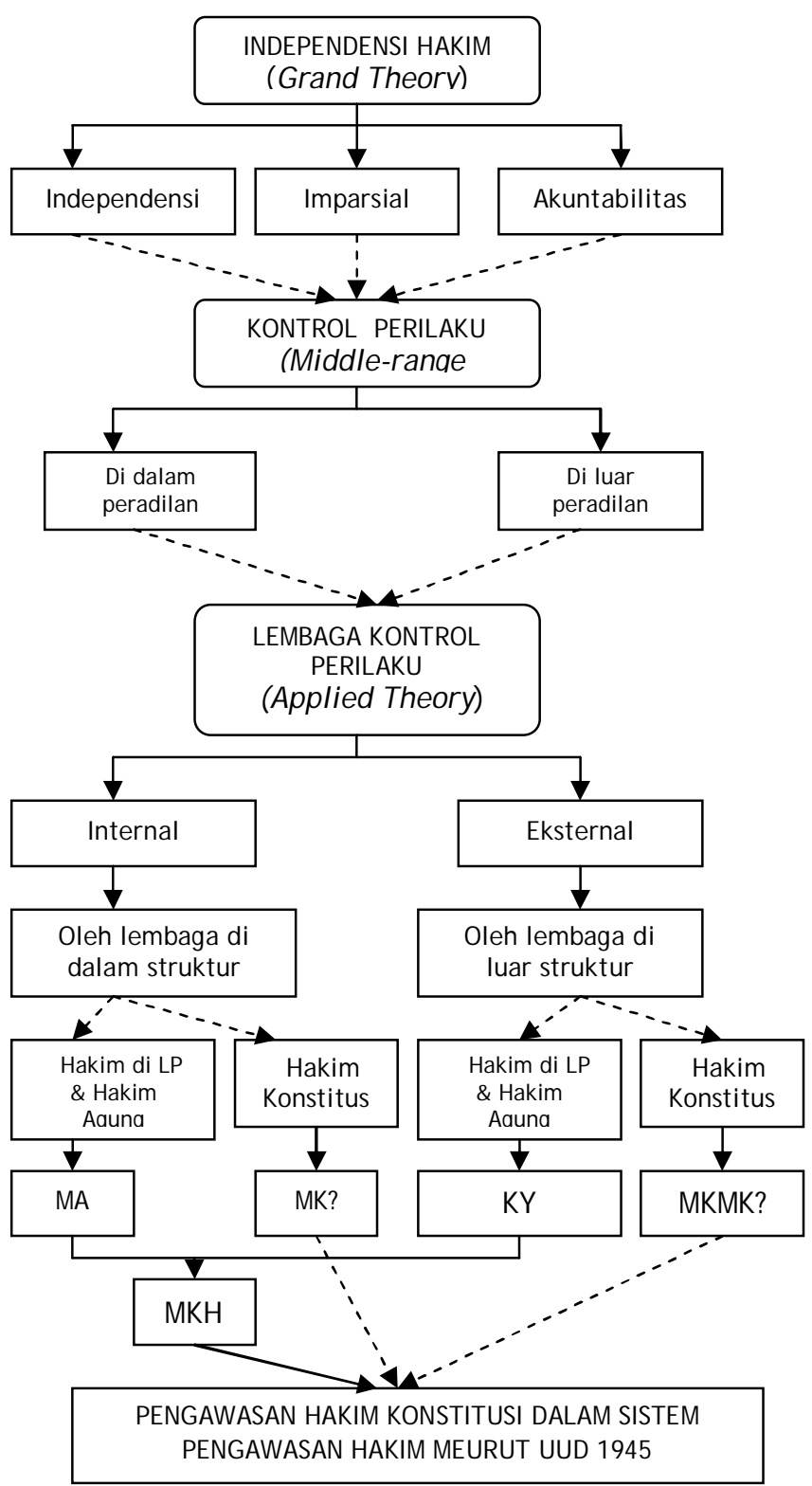

Berbagai Konsep Hakim Konstitusi Menurut Aturan Hukum

Konsep Hakim Konstitusi Menurut UUD 1945

Pasal 24 B ayat (1) UUD 1945 menentukan Komisi Yudisial bersifat mandiri yang berwenang mengusulkan pengangkatan hakim agung dan mempunyai wewenang lain

35 J ames W. McElhaney, "J udges and Magistrates, Litigation, Attorneys, Trial Preparation", ABA J ournal Chicago, No. 94 J anuary 2007, hlm. 22 
dalam rangka menjaga dan menegakkan kehormatan, keluhuran martabat, serta perilaku hakim.

Tidak ada tafsiran pada tingkat konstitusi berkaitan dengan makna hakim dalam kalimat "dalam rangka menjaga dan menegakkan kehormatan, keluhuran martabat, serta perilaku "hakim", artinya UUDNRI 1945 tidak menjelaskan hakim mana yang dimaksud dengan "hakim" dalam ketentuan Pasal 24B ayat (1) UUD 1945 tersebut, tetapi MK menerjemahkan "hakim" dalam ketentuan tersebut excluding Hakim Konstitusi. Putusan MK Nomor 005/PUU-IV/ 2006, tanggal 23 Agustus 2006, tidak memasukkan Hakim Konstitusi dalam lingkup pengawasan Komisi Yudisial (selanjutnya disebut KY), karena menurut MK pengertian hakim menurut Pasal 24B ayat (1) UUDNRI 1945 tidak termasuk Hakim Konstitusi, hal ini dengan beberapa pertimbangan. Pertama, secara sistematis perumusan ketentuan mengenai KY tidak berkaitan dengan ketentuan mengenai MK (pasal tentang $K Y$ ditempatkan lebih dahulu daripada pasal tentang MK); kedua, fungsi pengawasan terhadap perilaku Hakim Konstitusi dilakukan oleh Majelis Kehormatan; ketiga, makna hakim Konstitusi berbeda dengan Hakim biasa, karena hakim konstitusi pada dasarnya bukan hakim sebagai profesi tetap, tetapi hakim karena jabatannya; keempat, dalam keseluruhan mekanisme pemilihan dan pengangkatan para Hakim Konstitusi yang diatur dalam UUD 1945 tidak terdapat keterlibatan peran KY sama sekali; dan kelima, secara subtantif, jika perilaku hakim Konstitusi menjadi obyek pengawasan KY, maka kewenangan MK sebagai pemutus kewenangan konstitusional lembaga negara menjadi terganggu dan terj ebak ke dalam pihak yang tidak dapat bersikap imparsial. ${ }^{36}$

MK memiliki pendapat berbeda tentang Hakim Agung. Menurut MK, bahwa dari perspektif spirit of the constitution hakim agung termasuk dalam makna hakim, sehingga penga-

36 Lihat Putusan Mahkamah Konstitusi Nomor 005/PUUIV/ 2006 tentang Pengujian Undang-Undang Nomor 22 Tahun 2004 tentang Komisi Yudisial dan Undang-Undang Nomor 4 Tahun 2004 tentang Kekuasaan Kehakiman terhadap Undang-Undang Dasar Republik Indonesia Tahun 1945. Ioc. cit. wasannya menjadi aspek pengawasan $\mathrm{KY}$, hal ini dengan beberapa pertimbangan. Pertama, dari konteks sosial yang lebih luas, pengertian umum dan prinsip konstitusi hakim agung termasuk dalam kategori hakim; kedua, mekanisme pengangkatan hakim agung melibatkan keberadaan $\mathrm{KY}$, sehingga $\mathrm{KY}$ memiliki peran untuk tetap menjaga integritas dan kualitas perilakunya; ketiga, secara faktual Hakim Agung merupakan anggota Ikatan Hakim Indonesia (IKAHI) dan bahwa hakim agung adalah hakim, tidak pernah dipersoalkan. ${ }^{37}$

Jika ditelaah pendapat MK tersebut terdapat ketidakkonsistensian dan mengandung kelemahan, karena konstitusi secara tegas mengatakan, bahwa kekuasaan kehakiman dilakukan oleh MA dan MK. Dengan demikian sebagai konsekuensi kekuasaan kehakiman, hakim konstitusi tidak dapat dikeluarkan dari definisi hakim menurut Pasal 24B ayat (1) UUD 1945. Oleh karena kekuasaan kehakiman dilaksanakan oleh hakim dalam semua lingkungan peradilan, maka konsekuensinya hakim konstitusi termasuk dalam pengertian hakim. Selain itu dalam risalah perubahan UUD 1945, tidak pernah disebutkan bahwa hakim konstitusi tidak termasuk dalam pengertian hakim, dan ketentuan perundangundangan tidak memisahkan pengertian hakim berdasarkan ruang lingkup, sehingga semua hakim dalam ranah kekuasaan kehakiman termasuk hakim konstitusi harus dimaksudkan sebagai hakim.

\section{Konsep Hakim Konstitusi Menurut Undang- Undang}

Konsep Hakim Konstitusi dalam konteks Indonesia, secara yuridis diatur dalam undangundang yang terkait dengan kekuasaan kehakiman, yaitu Undang-undang tentang Kekuasaan Kehakiman, dan Undang-undang tentang Mahkamah Konstitusi serta Undang-Undang tentang Komisi Yudisial.

\section{Konsep Hakim Konstitusi Menurut Undang- Undang Kekuasaan Kehakiman}

\footnotetext{
37 Ibid.
} 
Undang-Undang yang mengatur mengenai Ke-kuasaan Kehakiman dalam Sistem Ketatanegaraan Indonesia, secara historis kronologis meliputi Undang-Undang No. 19 Tahun 1948 tentang Susunan dan Kekuasaan Badan-Badan Kehakiman dan Kejaksaan, Undang-Undang No. 19 Tahun 1964 tentang Ketentuan-Ketentuan Pokok Kekuasaan Kehakiman, Undang-Undang No. 14 Tahun 1970 tentang Ketentuan-Ketentuan Pokok Kekuasaan Kehakiman (UUKK 1970) yang telah diubah dengan Undang-Undang No. 35 Tahun 1999 tentang Perubahan Atas UndangUndang No. 14 Tahun 1970 tentang KetentuanKetentuan Pokok Kekuasaan Kehakiman (UUKK 1999), Undang-Undang No. 4 Tahun 2004 tentang Kekuasana Kehakiman (UUKK 2004) dan Undang-Undang No. 48 Tahun 2009 tentang Kekuasaan Kehakiman (UUKK 2009).

UUKK 2004 secara eksplisit tidak mendefinisikan apa itu Hakim Konstitusi. Pasal 12 yang mengatur tentang MK hanya menyebutkan mengenai tugas dan wewenang dari MK. Bagaimana dengan 'Makna Hakim Konstitusi dalam Konteks Makna Hakim'? Sebagaimana juga daIam UUKK 1970, dalam UUKK 2004 juga terdapat Bab khusus yang mengatur mengenai Hakim dan Kewajibannya, yaitu dalam Bab IV Hakim dan Kewaj ibannya.

UUKK 2004 mengatur mengenai kekuasaan kehakiman serta mencoba meletakkan prinsip-prinsip dasar kekuasaan kehakiman. Kekuasaan Kehakiman pada dasarnya merupakan suatu cabang kekuasaan Negara yang dibedakan dengan cabang kekuasaan Negara lainnya, yaitu eksekutif dan legislatif. Dalam kekuasaan kehakiman, Hakim merupakan komponen utama yang diperlukan untuk dapat menjalankan kekuasaan ini. Istilah Hakim merupakan istilah yang khas dalam kekuasaan ini yang membedakan dengan lembaga penyelesaian sengketa lainnya, seperti mediasi, arbitrase maupun yang lainnya. Meskipun hakim terbagi dalam beberapa lingkungan peradilan maupun mahkamah, namun ditinjau dari sudut fungsi, hingga simbol-simbol, seperti penggunaan toga, paIu, posisi ruang sidang dan dan lain sebagainya pada prinsipnya tidak ada perbedaan yang mendasar antara hakim pada Mahkamah Agung serta peradilan di bawahnya dengan hakim pada Mahkamah Konstitusi.

Berdasarkan ketentuan tersebut, ditinjau dari undang-undang yang mengatur mengenai Kekuasaan Kehakiman kecuali UUKK 2009, terlihat jelas bahwa dalam ketentuan UU tersebut tidak pernah membedakan pengertian hakim sehingga yang dimaksud dengan hakim adalah seluruh hakim mulai dari hakim pada tingkat pertama hingga Hakim Agung serta Hakim Konstitusi setelah unsur pranata MK ini dibentuk.

\section{Konsep Hakim Konstitusi dalam Undang- Undang Mahkamah Konstitusi}

Konsep Hakim Konstitusi menurut Undang-Undang Nomor 24 Tahun 2003 tentang Mahkamah Konstitusi (UUMK 2003) yang telah diubah berdasarkan Undang-Undang Nomor 8 Tahun 2011 tentang Perubahan Atas UndangUndang Nomor 24 Tahun 2003 tentang Mahkamah Konstitusi (UUMK 2011) hanya terdapat daIam satu Pasal, yaitu Pasal 5 yang menentukan bahwa Hakim Konstitusi adalah pejabat Negara. UUMK 2003 maupun UUMK 2011 tidak menjelaskan apa yang dimaksud dengan pejabat Negara itu? Istilah pejabat Negara dapat ditemukan dalam Undang-Undang Nomor 28 Tahun 1999 tentang Penyelenggaraan Negara Yang Bersih dan Bebas dari Korupsi, Kolusi dan Nepotisme Bab I Ketentuan Umum Pasal 1 ang-ka 1, bahwa Penyelenggara Negara adalah pejabat Negara yang menjalankan fungsi eksekutif, legislatif, atau yudisial ....".

Selain itu istilah hakim semata dalam UUMK 2003 hanya terdapat dalam Pasal 45 ayat (1) Bagian Ketujuh tentang Putusan yang menetapkan: "Mahkamah Konstitusi memutus perkara berdasarkan Undang-Undang Dasar Republik Indonesia Tahun 1945 sesuai dengan alat bukti dan keyakinan hakim." Dari ketentuan Pasal tersebut, jelas istilah hakim pada konteks keyakinan hakim digunakan untuk menunjuk pengertian Hakim Konstitusi. Ketentuan itu juga dapat dilihat, jika ditinjau kembali pada proses pembahasan UUMK 2003 pada Rapat Pansus UUMK 2003 terdapat aspirasi untuk memasukkan hakim konstitusi dalam makna hakim 
menurut Pasal 24B UUD 1945. Hal ini sebagaimana dikemukakan oleh J imly Asshiddiqie:

“... ketika RUUMK sedang dibahas oleh DPR dan pemerintah, tim ahli Pemerintah menyarankan agar ha-kim konstitusi juga ditentukan se-bagai hakim yang diawasi oleh Ko-misi Yudisial dengan menafsirkan kata 'hakim' dalam Pasal 24B UUD 1945 secara luas. Akan tetapi, semua anggota Pansus UUMK yang sebagian besar adalah mantan anggota Panitia Ad Hoc BP MPR yang terlibat dalam perumusan ketentuan Pasal 24A, Pasal 24B, dan Pasal 24C UUD 1945, semua menolak karena alasan bahwa hal itu bertentangan dengan maksud UU 1945." 38

Berdasarkan risalah tersebut, jelaslah bahwa memang sejak semula ada keinginan untuk memasukkan hakim konstitusi dalam makna 'hakim' sebagaimana ketentuan Pasal 24B UUDNRI 1945, meski hal ini kemudian tidak diakomodasi dalam ketentuan pasal-pasal dalam UUMK 2003.

\section{Konsep Hakim Konstitusi Menurut Undang- Undang Nomor 22 Tahun 2003 tentang Komisi Yudisial}

Konsep dan perumusan Hakim Konstitusi hanya include dalam Konteks Makna Hakim dalam Undang-Undang Nomor 22 Tahun 2003 tentang Komisi Yudisial diatur pada Pasal 1 angka 5 yang menentukan bahwa Hakim adalah hakim Agung dan hakim pada badan peradilan di semua lingkungan peradilan yang berada di bawah Mahkamah Agung serta hakim Mahkamah Konstitusi.

Perluasan makna hakim yang menyangkut pengertian Hakim Konstitusi dalam konteks Pasal 1 angka 5 UUKY 2004 pada dasarnya merupakan tafsir terhadap Pasal 24B ayat (1) UUD 1945 berdasarkan risalah-risalah sidang PAH BP MPR RI. Hal sebagaimana dikemukakan oleh Faj rul Falaakh:

Persoalan makna kata 'hakim' dalam ketentuan konstitusi tersebut, tidak ada penafsiran resmi pada tingkat konstitusi, karena tidak terdapat penjelasan dalam

38 J imly Asshiddiqie, 2010, Perkembangan dan Konsolidasi Lembaga Negara Pasca Reformasi, Jakarta: Sinar Grafika, hlm. 113
UUD 1945. Dua sumber utama yang dapat digunakan sebagai pembantu untuk memahami adalah Risalah Sidang MPR dan bahan sosialisasi hasil-hasil amandemen konstitusi. Masalah ini telah dipahami melalui tiga metode penafsiran konstitusi: semantik, historis (original intent), dan struktural. Penafsiran semantik memahami kata hakim sebagai-mana dituliskan, sehingga ketentuan anak kalimat ke dua Pasal 24B ayat (1) UUD 1945 memang mencakup semua hakim. Ini digunakan dalam bahan sosialisasi hasil-hasil amandemen oleh MPR. Pemahaman ini pula yang kemudian muncul dalam UU No. 4/ 2004 tentang Kekuasaan Kehakiman maupun dalam UUKY. ${ }^{39}$

Berdasarkan risalah-risalah sidang PAH BP MPR RI terdapat keinginan agar kompetensi KY mencakup semua hakim, termasuk promosi dan mutasi hakim, maupun merekomendasikan pengangkatan hakim MK, namun terdapat pula keinginan yang terbatas. Usulan dengan caku-pan luas ini tidak direkomendasi. Jadi, ada yang menginginkan terbatas (hakim agung saja) dan ada yang menginginkan cakupan yang luas (semua hakim), tetapi tidak terdapat catatan tentang pihak yang tidak ingin mencakup hakim agung. Kesimpulannya, kata 'hakim' yang bersifat umum disetujui namun hanya mengenai 'wewenang lain dalam rangka menjaga dan menegakkan kehormatan, keluhuran martabat, serta perilaku hakim." Ketentuan ini selanjutnya yang dirumuskan dalam Pasal 1 angka 5 UUKY 2004, bahwa hakim adalah Hakim Agung dan Hakim pada badan peradilan di semua lingkungan peradilan yang berada di bawah Mahkamah Agung serta Hakim Konstitusi".

\section{Lembaga Pengawas Hakim Konstitusi Menurut Putusan Mahkamah Konstitusi No. 005/PUU- IV/2006}

MK dalam amar Putusan Mahkamah Konstitusi Nomor 005/PUU-IV/ 2006 tentang Uji Materiil Undang-Undang Nomor 22 Tahun 2004 Tentang Komisi Yudisial dan Undang-Undang

\footnotetext{
39 Mohammad Fajrul Falakh, "Beberapa Pemikiran untuk Revisi UU Komisi Yudisial", dalam Komisi Yudisial, tth, Bunga Rampai Refleksi Satu tahun Komisi Yudisial RI, J akarta: Komisi Yudisial RI, hlm. 218-219
} 
Nomor 4 Tahun 2004 tentang Kekuasaan Kehakiman terhadap UUDNRI 1945, menyatakan:

Pengertian hakim menurut Pasal 24B ayat (1) UUD 1945 yang meliputi Hakim Konstitusi terbukti bertentangan dengan UUD 1945 ... Dengan demikian Hakim Konstitusi tidak termasuk pengertian hakim yang perilaku etiknya diawasi oleh Komisi Yudisial. Pengawasan terhadap pelaksanaan kode etik Hakim Konstitusi dilakukan oleh Majelis Kehormatan yang tersendiri sesuai dengan keten-tuan Pasal 23 UUMK sebagai pelak-sanaan Pasal 24C ayat (6) UUD 1945.

Jika mencermati secara seksama ketentuan UUD 1945 secara tegas mengatakan bahwa kekuasaan kehakiman dilakukan oleh Mahkamah Agung dan Mahkamah Konstitusi. ${ }^{40}$ Dengan demikian sebagai pelaksana kekuasaan kehakiman, Hakim Konstitusi tidak dapat dikeluarkan dari definisi hakim menurut Pasal 24B ayat (1) UUD 1945. Pasal 24 ayat (2) menentukan

Kekuasaan kehakiman dilakukan oleh sebuah Mahkamah Agung dan badan peradilan di bawahnya dalam lingkungan peradilan umum, lingkungan peradilan agama, dan lingkungan peradilan militer, serta lingkungan peradilan tata usaha negara dan oleh Mahkamah Konsti-tusi."

Ketentuan ini dipertegas kembali dalam Pasal 1 angka 1 Undang-Undang Nomor 24 Tahun 2003 tentang Mahkamah Konstitusi, yang menentukan bahwa Mahkamah Konstitusi adalah salah satu pelaku kekuasaan kehakiman sebagaimana dimaksud dalam Undang-Undang Dasar Negara Republik Indonesia Tahun 1945, dan Penegasan kedudukan MK diatur kembali dalam Pasal 2 Undang-Undang Nomor 24 Tahun 2003 tentang Mahkamah Konstitusi yang menentukan bahwa Mahkamah Konstitusi merupakan salah satu

40 Model pemisahan demikian tidak dikenal di negara-negara yang menganut sistem Anglo Saxon seperti di Amerika dan Australia. Di Australia tugas dan wewenang MK include dalam tugas dan wewenang MA, sehingga MA di negara ini juga berfungsi sebagai Guardian of Constitutional. T. Wij ayanta, "Tinjauan Yuridis tentang Mahkamah Agung dan High Court od Australia dalam Kaitannya dengan Penegakkan Hukum (Rule of Law)", Jurnal Mimbar Hukum Vol. X No. 3 Nopember 2002, Fakultas Hukum Universitas Gadjah Mada, hlm. 181. Lihat juga Deni Bram, "Tinjauan Teori Hukum Kehadiran Mahkamah Konstitusi di Indonesia", Jurnal Themis, Vol. II No. 1 Oktober 2007, hlm. 88 lembaga negara yang melakukan kekuasaan kehakiman yang merdeka untuk menyelenggarakan peradilan guna menegakkan hukum dan keadilan.

Berdasarkan konstruksi hukum demikian, menurut penulis karena kekuasaan kehakiman dilaksanakan oleh hakim dalam semua lingkungan peradilan maka tidak tepat mengatakan bahwa hakim konstitusi tidak termasuk dalam pengertian hakim, bahkan dalam risalah perubahan UUD 1945, tidak pernah disebutkan bahwa hakim konstitusi tidak termasuk dalam pengertian hakim, dan ketentuan perundangundangan tidak memisahkan pengertian hakim berdasarkan ruang lingkup, sehingga semua hakim dalam ranah kekuasaan negara termasuk hakim konstitusi haruslah dimaksudkan sebagai hakim. Makna inilah yang kemudian diadopsi dalam ketentuan Undang-Undang Nomor 22 Tahun 2004 tentang Komisi Yudisial. Artinya, bahwa perluasan 'makna hakim' yang menyangkut pengertian Hakim Konstitusi dalam konteks Pasal 1 angka 5 UUKY pada dasarnya meru-pakan tafsir terhadap Pasal 24B ayat (1) UUD 1945 berdasarkan risalah-risalah sidang PAH BP MPR RI. Berdasarkan risalah-risalah sidang PAH BP MPR RI terdapat keinginan agar kompetensi KY mencakup semua hakim, termasuk promosi dan mutasi hakim, maupun merekomendasikan pengangkatan hakim MK, namun terdapat pula keinginan yang ter-batas. Dengan demikian hakim konstitusi ju-ga merupakan hakim yang mekanisme penga-wasannya dilakukan oleh $\mathrm{KY}$.

Permasalahan kedua menyangkut kedudukan hukum dari MKMK, bahwa MKMK merupakan lembaga ad hoc, artinya apakah lembaga ad hoc layak melakukan pengawasan terhadap lembaga yang bersifat permanen sebagaimana MK? Harjono mengatakan, bahwa fungsi menjaga dan menegakkan kehormatan, keluhuran martabat, serta perilaku hakim tidak bisa dilakukan oleh lembaga ad hoc. Ini adalah fungsi yang bersifat permanen, sehingga dibutuhkan lembaga yang juga permanen.$^{41}$.

\footnotetext{
41 Harjono, “Lembaga Negara dalam UUD 1945", J urnal Konstitusi, Vol. IV No. 2 J uni 2007, hlm. 101-113. Lihat juga M. Agus Santoso, "Peran Dewan Perwakilan Rakyat Daerah dalam Menjalankan Fungsi Pengawasan", J urnal
} 
Berdasarkan pendapat tersebut, menurut penulis untuk membangun mekanisme pengawasan terhadap perilaku Hakim Konstitusi diperlukan lembaga independen, mandiri dan bersifat permanen hal ini dikarenakan fungsi tersebut bersifat permanen. Selain itu untuk menjaga integritas dan mempertahankan performa kelembagaan yang lebih baik diperlu-kan mekanisme pengawasan terpadu yang melibatkan lembaga di luar MK, sebagaimana mekanisme pengawasan di lembaga MA.

\section{Lembaga Pengawas Hakim Konstitusi dalam Sistem Pengawasan Hakim Menurut UUD 1945}

Pengawasan terhadap perilaku hakim konstitusi adalah mutlak adanya dan merupakan harga mati yang tidak dapat ditawar lagi. Menafikan pengawasan terhadap hakim konstitusi dan meniadakan peran lembaga eksternal seperti Komisi Yudisial yang secara konstitusional memiliki kewenangan atas hal tersebut dalam pengawasan hakim konstitusi merupakan langkah mundur dalam membangun puncak lembaga peradilan sebagai institusi dengan prinsip clean government dan good governance.

Mahkamah Konstitusi dalam Cetak Biru Membangun Mahkamah Konstitusi Bab IV Mewujudkan Akuntabilitas dan Transparansi Mahkamah Konstitusi bagian B Tujuan Strategis Mahkamah Konstitusi menyatakan:

MK memiliki peran strategis dalam sistem ketatanegaraan, yang tercermin pada kewenangan-kewenangan yang dimilikinya ... untuk itu menjadi penting bagi MK, memberikan pengawasan terhadap integritas dan perilaku hakim kepada pihak eksternal yang memiliki kewenangan untuk itu. Komisi Yudisial, secara yuridis memiliki kewenangan untuk mengawasi hakim baik di lingkungan peradilan umum maupun MK. ${ }^{42}$

Terkait dengan kedudukan Komisi Yudisial selaku pengawas eksternal Hakim Konstitusi tersebut, J imly Asshiddiqie menyatakan:

Dari ketentuan mengenai Komisi Yudisial ... dapat dipahami bahwa jabatan hakim

Hukum lus Quita lustum Vol. XVIII No. 4 Oktober 2011, FH UII Yogyakarta, hlm. 614

42 Mahkamah Konstitusi RI, 2006, Cetak Buru Membangun Mahkamah Konstitusi, J akarta: Mahkamah Konstitusi RI, hlm. 121 dalam konsepsi UUD 1945 dewasa ini adalah jabatan kehormatan yang perlu dijaga dan ditegakkan kehormatannya oleh suatu lembaga yang juga bersifat mandiri, yaitu Komisi Yudisial yang merupakan pengembangan lebih lanjut ide pembentukan Majelis Kehormatan Hakim Agung yang ditarik ke luar ... oleh karena itu, keberadaan lembaga Komisi Yudisial ini dibentuk tersendiri di luar Mahkamah Agung, sehingga subyek yang diawasinya dapat diperluas ke semua hakim, termasuk hakim konstitusi dan hakim di seluruh Indonesia. ${ }^{43}$

Selanjutnya Jimly Asshiddiqie, juga mengatakan:

“... Berdasarkan penafsiran harfiah, hakim konstitusi pun pula dimasukkan ke dalam pengertian hakim yang diawasi menurut ketentuan Pasal 24B ayat (1) UUD 1945. Oleh karena itulah UUKY menganut pengertian yang terakhir ini, yaitu menafsirkan kata 'hakim' dalam Pasal 24B ayat (1) UUD 1945 secara luas sehingga mencakup seluruh hakim dalam lingku-ngan MA dan semua hakim pada MK .... Dengan demikian, KY berfungsi sebagai lembaga pengawas MK, melalui kewenangannya untuk menjaga dan menegakkan kehormatan, keluhuran martabat, serta perilaku para hakim konstitusi sebagaimana mestinya" ${ }^{44}$.

M. Laica Marzuki juga menyatakan:

“Konstitusi memberikan kewenangan kepada Komisi Yudisial guna menjaga dan menegakkan kehormatan, keluhuran martabat serta perilaku hakim ... Hal dimaksud berkaitan dengan kewenangan Komisi melaku-kan pengawasan terhadap perilaku hakim ... Kewenangan pengawasan demikian juga berlaku terhadap peri-lakuperilaku Hakim Konstitusi ..." ${ }^{45}$

Berdasarkan ketentuan Cetak Biru MK dan pendapat para ahli hukum tersebut, jelaslah bahwa pada dasarnya MK membuka diri terha-

43 Jimly Asshiddiqie, 2005, Kedudukan Mahkamah Konstitusi dalam Struktur Ketatanegaraan Indonesia, dalam Mahkamah Konstitusi, Bunga Rampai Mahkmah Konstitusi RI, J akarta: Setjen dan Kepaniteraan Mahkamah Konstitusi RI, hlm. 35

44 Ibid., h. 38

45 M. Laica Marzuki, "Komisi Yudisial dan Relevansinya dengan Kekuasaan Kehakiman", J urnal Konstitusi, Vol. VI No. 2 2006, hlm. 86 
dap mekanisme pengawasan eksternal terhadap integritas dan perilaku hakim dan secara eksplisit melegitimasi keberadaan KY sebagai lembaga pengawas Hakim selain Majelis Kehormatan MK dan kontrol masyarakat. Dalam konteks yang lebih luas, dalam hal ini memberi sinyal bahwa "subyek yang diawasi KY dapat diperluas ke semua hakim, termasuk hakim konstitusi", sehingga perilaku Hakim Konstitusi termasuk yang diawasi Komisi Yudisial ${ }^{46}$.

Membandingkan keberadaan lembaga pengawasan hakim konstitusi di negara-negara yang konstitusinya mengadakan lembaga tersebut khususnya di negara-negara Eropa. Ketentuan mengenai keberadaan lembaga pengawasan Hakim Konstitusi berbeda-beda di setiap negara yang konstitusinya mengadakan lembaga tersebut. Setidaknya terdapat tiga model utama yang berlaku di Eropa dalam hubungan antara Hakim Konstitusi sebagai unsur yang ada dalam lembaga peradilan, Komisi Yudisial atau lembaga serupa lainnya dan para pejabat yang berwenang. Pertama, model Eropa Utara. Model Eropa Utara memberikan wewenang yang luas kepada Komisi Yudisial, termasuk kewenangan dalam bidang penganggaran, logistik, kontrol, pengawasan, pengangkatan, tindalan disipliner, perekrutan dan aspek lain yang berkaitan dengan lembaga peradilan (seperti pengawasan terhadap administrasi peradilan, keuangan pengadilan, manajemen perkara, bahkan sampai dengan manajemen pengadilan (seperti perumahan hakim, pendidikan hakim dan sebagainya). Model ini dianut oleh negara Swedia, Irlandia dan Denmark. Kedua, Model Eropa Selatan. Menurut model ini kewenangan Komisi Yudisial hanya untuk memberikan nasehat dalam pengangkatan hakim dan pegawai pengadilan serta kewenangan untuk mengambil tindakan disipliner terhadap hakim. Contoh model ini adalah negara Italia, Perancis, Spanyol, Portugal dan Swiss. Ketiga, model tak terbagi (undivided model). Model ini tidak ada lembaga

46 Lihat mengenai perbandingan keberadaan Komisi Yudisial dalam sistem ketatanegaraan di beberapa negara pada J ames Podgers, "To Make Survive of J udical Commission", ABA J ournal Chicago, Vol. 82 Oktober 2002, hlm. 112. Lihat J uga Titik Triwulan Tutik, "Kedudukan dan Fungsi Komisi Yudisial sebagai Lembaga Negara dalam Sistem Ketatanegaraan Republik Indonesia", J urnal IImu Hukum Yuridika Vol. 21 No. 4 Juli-Agustus 2006, Fakultas Hukum Uiversitas Airlangga, hlm. 367 perantara seperti Komisi Yudisial dalam hal pengelolaan pengadilan, melainkan pengelolaannya diserahkan kepada badan pemerintah yang berwenang. Model tak terbagi dianut oleh Belanda dan J erman ${ }^{47}$.

Konstitusi Afrika Selatan meletakkan kedudukan Komisi Yudisial (J udicial Service Commision) di Afrika Selatan di luar Bab tentang Kekuasaan Kehakiman ${ }^{48}$, dan secara fungsi memiliki kewenangan yang lebih luas dari KY di Indonesia. Komisi ini memiliki fungsi memberikan advis (rekomendasi) kepada Presiden dalam pengangkatan dan pemberhentian Ketua dan Wakil Ketua MK, Ketua dan wakil Ketua MA, dan hakim di semua lembaga peradilan. ${ }^{49}$

\section{Penutup \\ Simpulan}

Ada dua simpulan yang dapat diutarakan berdasarkan pembahasan di atas. Pertama, UUD 1945 secara rinci tidak memberikan penjelasan mengenai hakim mana saja yang dimaksud dalam makna hakim Pasal 24B ayat (1) UUD 1945 dalam kalimat "dalam rangka menjaga dan menegakkan kehormatan, keluhuran martabat, serta perilaku hakim", tetapi berdasarkan Pasal 24 ayat (2) UUD 1945 bahwa kekuasaan kehakiman dilakukan oleh sebuah Mahkamah Agung dan badan peradilan yang berada di bawahnya dalam lingkungan peradilan umum, lingkungan peradilan agama, lingkungan peradilan militer, lingkungan peradilan tata usaha negara, dan oleh sebuah Mahkamah Konstitusi, maka istilah hakim adalah keseluruhan hakim yang menjalankan fungsi Kekuasaan Kehakiman; pembedaan jenis-jenis hakim hanyalah dimaksudkan untuk membedakan fungsi dari masing-masing jenis hakim tersebut, untuk Hakim Agung fungsinya adalah untuk menjalankan Kekuasaan Kehakiman di tingkat Mahkamah Agung, Hakim Tinggi menjalankan Kekuasaan Kehakiman di tingkat Pengadilan Tinggi (Banding); Hakim Negeri menjalankan Kekuasaan

47 Wim Voermans, 2002, Raden voor de rachtspraak in Iaden van de Europese Unie. Terj. Adi Nugroho dan M. Zaki Hussein, Komisi Yudisial di Beberapa Negara Uni Eropa, Jakarta: LelP, hlm. 7

48 M. Busyro Muqoddas, "Komisi Yudisial dalam Bingkai Sistem Ketatanegaraan RI", J urnal Mejelis, Vol. I (1) Agustus 2009, hlm. 118

49 Article 174 (3) dan (6); Article 177 ayat (3); dan Artikel 178 ayat (5) Kostitusi Afrika Selatan dalam Ibid. 
Kehakiman di Pengadilan Tingkat I, Hakim Konstitusi menjalankan Kekuasaan Kehakiman yang menjadi ruang lingkup Mahkamah Konstitusi dan hakim Ad Hoc menjalankan Kekuasaan Kehakiman pada bidang-bidang tertentu, dengan demikian hakim konstitusi adalah juga hakim. Kedua, merujuk pada Aturan Peralihan UUD 1945, menyatakan Mahkamah Konstitusi dibentuk selambat-lambatnya pada 17 Agustus 2003 dan sebelum dibentuk segala kewenangannya dilakukan oleh Mahkamah Agung. Dengan demikian, karena Hakim Agung menjalankan tugas sebagai Hakim Konstitusi atau dengan kata lain Hakim Agung bertindak sebagai Hakim Konstitusi, sehingga karena Hakim Agung termasuk dalam pengertian hakim, maka Hakim Konstitusi dalam kontek ini juga termasuk dalam pengertian hakim.

Mekanisme pengawasan hakim konstitusi yang hanya mengadopsi Majelis Kehormatan Hakim Konstitusi, memiliki kelemahan jika diandingkan dengan mekanisme pengawasan hakim menurut UUDNRI 1945, karena mekanisme pengawasan hakim pada dasarnya melibatkan 2 (dua) lembaga pengawas, yaitu pengawas internal dan pengawas eksternal yang melibatkan lembaga di luar struktur organisasi. Lembaga pengawas hakim yang mandiri, dan bebas dari campur tangan lembaga lain mutlak diperlukan dalam rangka menegakkan kehormatan, menjaga keluhuran martabat serta perilaku hakim dalam rangka mewujudkan pemerintahan yang baik dan bersih (good governance).

\section{Saran}

Mewujudkan sistem pengawasan peradilan terpadu yang memiliki legitimasi yang kuat ke masa depan, MPR harus melakukan amandemen UUDRI 1945 khususnya Bab Kekuasaan Kehakiman dengan melakukan beberapa hal. Pertama, menyatakan secara eksplisit dalam konstitusi bahwa yang dimaksud hakim meliputi hakim pada lembaga peradilan di bawah MA, hakim agung pada MA dan hakim konstitusi pada MK. Kedua, menata kembali sistematika lembaga yang terkait kekuasaan kehakiman dengan sistematika pasal tentang MA, pasal tentang $M K$, dan baru pasal tentang $K Y$, sehingga secara yuridis filosofis KY memiliki keterkaitan langsung dengan lembaga MA dan MK. Ketiga, menyatakan secara eksplisit dalam pasal-pasalnya bahwa KY merupakan lembaga yang memiliki wewenang lebih luas tidak sekedar sebagai lembaga yang memiliki kewenangan untuk melaksanakan rekrutmen, dan pengawasan terhadap hakim, hakim agung dan hakim konstitusi tetapi juga melakukan mutasi, pelatihan, promosi dan kebijakan tentang anggaran lembaga peradilan.

\section{Daftar Pustaka}

Adji, Oemar Seno. 1985. Peradilan Bebas Negara Hukum. Jakarta: Erlangga;

Arizona, Yance. "Konstitusi dalam Intaian Neoliberalisme". Jurnal Konstitusi. Vol. I. No. 1 November 2008. J akarta: Mahkamah Konstitusi Rl;

Ashar, Ahmad. "Kewenangan Komisi Yudisial dalam Pengangkatan Hakim Agung Berdasarkan pada UU Nomor 22 Tahun 2004 tentang Komisi Yudisial". Jurnal DAHA, Vol. I No. 42. J anuari 2009. Kediri: Universitas Pawiyatan Daha;

Asshiddiqie, Jimly. "Pemilihan Langsung Presiden dan wakil Presiden". J urnal Hukum. Vol XXVII. No. 51 2004. Yogyakarta: FH UII;

2005. Kedudukan Mahkamah Konstitusi dalam Struktur Ketatanegaraan Indonesia. dalam Mahkamah Konstitusi, Bunga Rampai Mahkmah Konstitusi RI, J akarta: Setjen dan Kepaniteraan Mahkamah Konstitusi;

-----. 2010. Perkembangan dan Konsolidasi Lembaga Negara Pasca Reformasi. Jakarta: Sinar Grafika;

Astriyani. "Mewujudkan Komisi Yudisial yang Ideal utuk Menjaga dan Menegakkan Kehormatan serta Keluhuran Martabat $\mathrm{Ha}$ kim". Jurnal Hukum, Vol. III No. 8. Mei 2004. J akarta: Fakultas Hukum UI;

Bram, Deni. "Tinjauan Teori Hukum Kehadiran Mahkamah Konstitusi di Indonesia" J urnal Themis. Vol. II. No. 1. Oktober 2007. Jakarta: FH Universitas Pancasila;

Chotidjah, Nurul. "Dinamika Implementasi Kewenangan Mahkamah Agung dan Komisi Yudisial setelah Amandemen UndangUndang Dasar 1945". Jurnal IImu Hukum Litigasi. Vol. IX. No. 3. 2008. Bandung: Fakultas Hukum Universitas Pasundan;

-.-.--.. “Eksistensi Komisi Yudisial dalam Mewujudkan Kekuasaan Kehakiman yang Mer- 
deka". Jurnal IImu Hukum Syiar Hukum. Vol. XII No. 2 J uli 2010. Bandung: FH Universitas Islam Bandung;

Falakh, Mohammad Fajrul. tt. Beberapa Pemikiran untuk Revisi UU Komisi Yudisial. Bunga Rampai misi Yudisial RI. Jakarta: Komisi Yudisial;

Ferejohn, John. "Independent Judges, Dependent J udiciary: Explaining J udicial Independence". 72 Southern California Law Review 353;

Hadjon, Philipus M. "Pengkajian IImu Hukum Dogmatik (Normatif)". Jurnal Yuridika. Vol. IX. No. 6. November-Desember 1994. Surabaya: FH Universitas Airlangga;

Harjono. "Lembaga Negara dalam UUD 1945". J urnal Konstitusi. Vol. IV No. 2 J uni 2007. J akarta: Mahkamah Konstitusi;

Heryanto, Bambang. "Refleksi Politik Hukum Pelanggaran Hak Asasi Manusia di Indonesia". J urnal Ilmu Hukum Yuridika. Vol. 17. No. 4. Juli-Agustus 2002. Surabaya: FH Universitas Airlangga;

Hutchinson, Terry. "Researching and Writing in Law" Lawbook. Co. Pyrmont-NSW-Sydney. 2002;

Indrayana, Denny. "Negara Hukum Indonesia Pasca Soeharto: Transisi Menuju Demokrasi vs Korupsi". J urnal Konstitusi. Vol. I. No. 1. Juli 2004. Jakarta: Mahkamah Konstitusi Rl;

Isra, Saldi. "Putusan Mahkamah Konstitusi Nomor 005/PUU-IV/2006: Isi, Implikasi dan Masa Depan Komisi Yudisial". Jurnal IImiah Hukum Legality. Vol. XV No. 12007. Malang: FH Universitas Muhammadyah;

Ketua Mahkamah Agung RI, "Pedoman Perilaku Hakim". Varia Peradilan. No. 252 Oktober 2006. J akarta: Mahkamah Agung Rl;

Kusuma, RM Ananda B. "Teori Konstitusi dan UUD 1945". Jurnal Konstitusi. Vol. III. No. 2 Mei 2006. Jakarta: Mahkamah Konstitusi;

Latif, Abdul. "Pilpres dalam Perspektif Koalisi Multipartai". J urnal Konstitusi. Vol. VI. No. 3. September 2009. Jakarta: Mahkamah Konstitusi;

Lotulung, Paulus E., "Kebebasan Hakim dalam Sistem Penegakan Hukum". Makalah disampaikan dalam Seminar Pembangunan Hukum Nasional VIII, diselenggarakarn oleh Badan Pembinaan Hukum Nasional Departemen Kehakiman dan Hak Asasi Manusia RI). Denpasar, 14 -18 juli 2003;
Machmudin, Dudu Duswara. "Peranan Keyakinan Hakim dalam Memutus suatu Perkara di Pengadilan". Varia Peradilan. Oktober 2006. J akarta: Mahkamah Agung Rl;

Mahkamah Agung RI. 2003. Cetak Biru Pembaruan Mahkamah Agung RI. J akarta: Kerjasama Mahkamah Agung RI dengan LeIP. The Asia Foundation, USAID \& Kemitraan;

Mahkamah Konstitusi RI. 2006. Cetak Buru Membangun Mahkamah Konstitusi, Jakarta: Mahkamah Konstitusi Rl;

Maladi, Yanis. "Benturan Asas Nemo Judex Indoneus In Propria Causa dan Asas lus Curita Novit: Telaah Yuridis Putusan Mahkamah Konstitusi Nomor 005/PUU-IV/ 2006". J urnal Konstitusi. Vol. VII. No. 2. 2010. J akarta: Mahkamah Konstitusi;

Malik. "Perspektif Fungsi Pengawasan Komisi Yudisial Pasca Putusan Mahkamah Konstitusi (MK) No. 005/ PUU-IV/2006". J urnal Hukum. Vol. 1 No. 2 Desember 2007. Padang: FH Universitas Bung Hatta;

Marzuki, M Laica. "Kesadaran Berkonstitusi daIam Kaitan Konstitusionalisme". J urnal Konstitusi. Vol. VI. No. 3. September 009. J akarta: Mahkamah Konstitusi Rl;

"Komisi Yudisial \& Relevansinya dengan Kekuasaan Kehakiman". J urnal Konstitusi. Vol. VI. No. 2. 2006. Jakarta: Mahkamah Kostitusi;

-.----. "Paradigma Kedaulatan Rakyat dalam Perubahan Undang-Undang Dasar 1945". J urnal Legislasi Indonesia. Vol. VII. No. 1. Maret 2010. Jakarta: DEPKUM-HAM Rl;

Marzukki, Peter Mahmud. "Jurisprudence As Sui Generis Discipline". J urnal Hukum Yuridika. Vol. XVII. No. 4. J uli 2002. Surabaya: $\mathrm{FH} \quad$ Universitas Airlangga;

McElhaney, J ames W. "J udges and Magistrates, Litigation, Attorneys, Trial Preparation". ABA J ournal Chicago. 94 J anuary 2007;

Mochtar, Zainal Arifin \& Iwan Satriawan "Efektivitas Sistem Penyelesaian Pejabat Komisi Negara di Indonesia". J urnal Konstitusi. Vol. VI No. 3 September 2009. Jakarta: Mahkamah Konstitusi;

Muchlis. "Hubungan Komisi Yudisial dengan Mahkamah Agung dalam Pengawasan Hakim". J urnal Suloh. Vol. VI No. 2. Agustus 2008. Lhokseumawe: FH Universitas Malikusshaleh;

Mulyono, Tristam P. "Negara Hukum dan Hukum Negara: Les Quatres Saisons", J urnal Proj ustitia Vol. XVIII No. 1. J anuari 
2002. Bandung: FH Universitas Parahyangan;

Muqoddas, M. Busyro. "Komisi Yudisial dalam Bingkai Sistem Ketatanegaraan Rl". J urnal Mejelis. Vol. I. No. 1. Agustus 2009;

Nurhasan. "Sistem Politik Peradilan Indonesia, Hakim dan Komisi Yudisial dalam Mewujudkan Penegakkan Hukum yang Efektif dan Efisien" Jurnal IImu Hukum Litigasi. Vol. IX. No. 3. 2008. Bandung: FH Universitas pasundan;

Petoewas, Berchah "Kewenangan Komisi Yudisial dalam Rangka Pengawasan Hakim Guna Melaksanakan Amanat UUD 1945". J urnal Hukum Adil. Vol. I No. 3 Desember 2010;

Pigome, Martha., "Implementasi Prinsip Demokrasi dan Nomokrasi dalam Struktur Ketatanegaraan RI Pasca Amandemen 1945". Jurnal Dinamika Hukum Vol. 11 No. 2 Mei 2001. Purwokerto: FH Universitas Jenderal Soedirman;

Podgers, James. "To Make Survive of J udical Commission". 82 Oktober 2002. ABA J ournal Chicago;

Rosita, Dian. "Mengkaji Ulang Konsep Rule of Law dalam Pembaharuan Peradilan di Indonesia". Jurnal Konstitusi. Vol. I No. 1. November 2008. J akarta: MK RI;

Saharuddin Daming, "Wabah The Dark Juctice dan Tirani Peradilan". Koran Tempo. Selasa 26 April 2011;

Santoso, M Agus. "Peran Dewan Perwakilan Rakyat Daerah dalam Menjalankan Fungsi Pengawasan". Jurnal Hukum lus Quita lustum. Vol. XVIII. No. 4. Oktober 2011. Yogyakarta: FH UII;

Setiawan, Wijayanto. "Peran Hakim Agung dalam Penemuan Hukum (Rechtsvinding) dan penciptaan Hukum (Rechtsschepping) pada Era Reformasi dan Transformasi". Jurnal Perspektif Hukum. Vol. VII No. 2 November 2007. Surabaya: FH Univ. Hang Tuah Surabaya;

Siahaan, Lintong O. "Peran Hakim dalam Pembaharuan Hukum di Indonesia". J urnal Hukum dan Pembangunan. Vol. 36 No. 1 J anuari-Maret 2006. J akarta: FH UI;

Simabura, Charles., "Membangun Sinergis daIam Pengawasan Hakim", J urnal Konstitusi. Vol. VII No. 2. Juli 2009. Jakarta: Mahkamah Konstitusi;

Soemantri, Sri. "Sistem Pemerintahan Republik Indonesia". Jurnal Mimbar Hukum. Vol.
X. No. 3. Nopember 2002. Yogyakarta: FH Universitas Gadjah Mada;

Soewoto. "Metode Interpretasi Hukum Terhadap Konstitusi", Jurnal Hukum Yuridika. Vol. V. No. 1. Januari-Februari 1990. Surabaya: FH Universitas Airlangga;

Thohari, A Ahsin. "Kedudukan Komisi-Komisi Negara dalam Struktur Ketatanegaraan Indonesia". J urnal Hukum J entera. Vol. III. No. 12 April- J uni 2006;

"Jalan Terjal Konstitusionalisme Indonesia". Jurnal Konstitusi. Vol. 1. No. 1 Juli 2004. Jakarta: Mahkamah Konstitusi $\mathrm{Rl}$;

"Desains Konstitutsional Komisi Yudisial dalam Sistem Ketatanegaraan Indonesia". J urnal Legislasi Indonesia. Vol. VII No. 1 Maret 2010;

Tutik, Titik Triwulan. "Kedudukan dan Fungsi Komisi Yudisial sebagai Lembaga Negara dalam Sistem Ketatanegaraan Republik Indonesia". J urnal IImu Hukum Yuridika. Vol. 21. No. 4. Juli-Agustus 2006. Surabaya: FH Uiversitas Airlangga;

Voermans, Wim. 2002. "Raden voor de Rechtspraak in laden van de Europese Unie". Terj. Adi Nugroho dan M. Zaki Hussein. Komisi Yudisial di Beberapa Negara Uni Eropa. J akarta: LelP;

Widawati, Ayudya. "Seleksi Hakim Agung 2008, Mencari Hakim Agung yang Profesional, Berkualitas, Berintegritas, kuntabel dan Transparan dalam Rangka Menegakkan Prinsip Check and Balances Kekuasaan Kehakiman di Indonesia" J urnal Hukum. Vol. VII No. 1. J uni 2008. J akarta: Fakultas Hukum Ul;

Widitrismiharto, Didik. "Pengutan Fungsi Pengawasan Komisi Yudisial Berada di Persimpangan J alan: Sebuah Kajian tentang Reformasi Peradilan". J urnal Yustika. Vol X. No. 2. Desember 2007. Surabaya: FH Ubaya;

Wignjosumarto, P. "Peran Hakim Agung dalam Penemuan Hukum dan Penciptaan Hukum pada Era Reformasi dan Transformasi". Varia Peradilan. 251 Oktober 2006. Jakarta: Mahkamah Agung Rl;

Wijayanta, T. "Tinjauan Yuridis tentang Mahkamah Agung dan High Court od Australia dalam Kaitannya dengan Penegakkan Hukum (Rule of Law)". J urnal Hukum. Vol. X. No. 3. Nopember 2002. Yogyakarta: FH Universitas Gadjah Mada. 